\title{
Recharge contribution to the Guarani Aquifer System estimated from the water balance method in a representative watershed
}

\author{
EDSON WENDLAND ${ }^{1}$, LUIS H. GOMES ${ }^{2}$ and UWE TROEGER ${ }^{3}$ \\ ${ }^{1}$ Universidade de São Paulo, Departamento de Hidráulica e Saneamento, \\ Av. Trabalhador Sãocarlense, 400, 13566-590 São Carlos, SP, Brasil \\ ${ }^{2}$ Departamento de Água e Energia Elétrica - DAEE, Av. Otávio Pinto Cesar, \\ 1400, 15085-360 São José do Rio Preto, SP, Brasil \\ ${ }^{3}$ Ernst-Reuter-Platz 1, Technische Universität Berlin, Institut für Angewandte \\ Geowissenschaften, Berlin, D-10587, Deutschland
}

Manuscript received on February 13, 2014; accepted for publication on September 5, 2014

\begin{abstract}
The contribution of recharge to regional groundwater flow systems is essential information required to establish sustainable water resources management. The objective of this work was to determine the groundwater outflow in the Ribeirão da Onça Basin using a water balance model of the saturated soil zone. The basin is located in the outcrop region of the Guarani Aquifer System (GAS). The water balance method involved the determination of direct recharge values, groundwater storage variation and base flow. The direct recharge was determined by the water table fluctuation method (WTF). The base flow was calculated by the hydrograph separation method, which was generated by a rain-flow model supported by biweekly streamflow measurements in the control section. Undisturbed soil samples were collected at depths corresponding to the variation zone of the groundwater level to determine the specific yield of the soil (drainable porosity). Water balances were performed in the saturated zone for the hydrological years from February 2004 to January 2007. The direct recharge ranged from $14.0 \%$ to $38.0 \%$, and groundwater outflow from $0.4 \%$ to $2.4 \%$ of the respective rainfall during the same period.
\end{abstract}

Key words: Groundwater, monitoring, recharge, specific yield, WTF.

\section{INTRODUCTION}

The increased water demand for domestic, industrial, and agricultural use associated with the rising deterioration of surface water has resulted in the need for having water that is available in large volumes, of good quality, relatively inexpensive and available over a long period of time. This situation has led to the increased use of groundwater. Therefore, the

Correspondence to: Edson Wendland

E-mail: ew@sc.usp.br quantification of groundwater recharge is a vital precondition for an efficient management of water resources (Moon et al. 2004, Dewandel et al. 2010), particularly in semi-arid regions (Scanlon et al. 2006, Smerdon et al. 2010) and areas where there is overexploitation (Hugman et al. 2012), i.e., the water extraction from the aquifer is higher than its natural replenishment. The identification of recharge sources and the definition of a conceptual model of flow mechanisms are of paramount importance. 
Water that moves downward from the surface below the root zone is termed as groundwater recharge, deep drainage or deep percolation. The ground water recharge is the most difficult component of the hydrological cycle to determine, and its estimates present a high degree of uncertainty. This fact is due in part to the lack of a direct measurement methodology and, subsequently, to the limited availability of existing information (Healy 2010). Depending on the number of sources and processes, recharge can be quantified by various methods (Lerner et al. 1990, Simmers 1989, Kinzelbach 2002). Each method has its own applicability and reliability limitations (Lerner et al. 1990, Beekman et al. 1996, De Vries and Simmers 2002, Healy and Cook 2002, Sanford 2002). Scanlon et al. (2002) presented a large variety of procedures for estimation of groundwater recharge.

For management (Arnold et al. 2000, Hirata and Conicelli 2012) and economic reasons (Raudsepp-Hearne et al. 2010) it is important to know how much water a recharge basin contributes to the regional flow system. This information is important since generally the groundwater is extracted in locations different from the recharge areas. Part of the groundwater recharge stored in the aquifer is drained to the gaining streams as base flow, characterizing the local flow systems (Fetter 1994). On the other hand, part of the groundwater recharge may leave the basin through the bottom boundary, flowing to deeper confined aquifers. This portion of groundwater recharge will be defined as groundwater outflow to the regional flow system. The exploitation for public water supply in other region may be seen as a basin contribution to ecosystem services (Naeem et al. 1997).

In this work the groundwater recharge at an outcrop zone is determined, and the contribution to the regional groundwater flow system of the Guarani Aquifer System (GAS), is evaluated. The GAS (Araújo et al. 1999, Sracek and Hirata 2002, Wendland et al. 2007, Rabelo and Wendland 2009,
Gómez et al. 2010) is one of the most important transboundary aquifers in the world. Located in the territory of four countries, Argentina, Brazil, Paraguay and Uruguay, its area is estimated to 1.2 million $\mathrm{km}^{2}$ (Foster et al. 2004). Due to the strategic, social and economic importance of this aquifer for the four countries, it is necessary to determine the recharge rate for management purposes. However, there are few scientific studies in this area and many questions are still unanswered.

The basic hypothesis is that the groundwater recharge and outflow to the regional flow system can be determined using the water balance method in the saturated zone of small basins with a dense instrumentation network for hydrogeological studies. This method avoids the uncertainties related to interception phenomena, evapotranspiration and soil moisture estimates. However, the procedure requires intensive monitoring of water level variation in the wells and a careful determination of the specific yield (drainable porosity) of the basin soil (Maréchal et al. 2006, Tan et al. 2007). For the present study the specific yield was determined in laboratory tests using undisturbed soil samples taken at various places and depths within the basin.

\section{LOCATION AND DESCRIPTION OF THE BASIN}

The Ribeirão da Onça basin is located in the Midwestern region of São Paulo, Brazil, in the city of Brotas, between the latitudes $22^{\circ} 10^{\prime}$ and $22^{\circ} 15^{\prime}$ South and the longitudes $47^{\circ} 55^{\prime}$ and $48^{\circ} 00^{\prime}$ West (Figure 1).

Most of the basin is located over sandstone layers of the Botucatu Formation, corresponding to the Guarani Aquifer System outcrop. Downstream, close to the basin outlet, the Ribeirão da Onça creek flows over diabase sills. Both units are part of the São Bento Group from the Mesozoic Era (Araújo et al. 1999). The geological section through the basin is shown in Figure 2. The Ribeirão da Onça basin is covered by Cenozoic sediments found in most of the interior of the state of São Paulo. This soil presents a thickness of generally less than $10 \mathrm{~m}$, often separated from the 


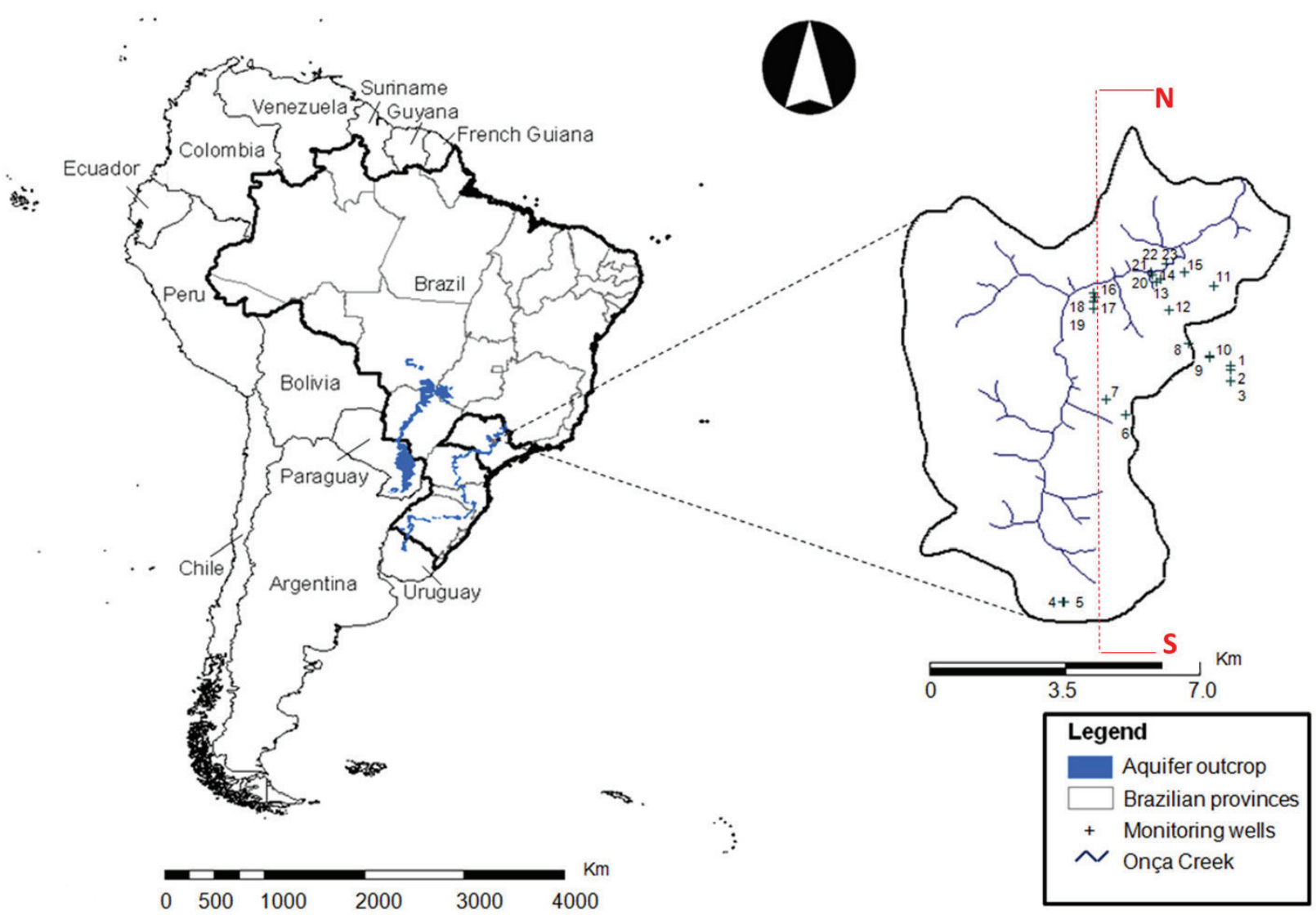

Figure 1 - Location of the Ribeirão da Onça basin (Manzione et al. 2012).

underlying layer by a line of pebbles (Bortolucci 1983). This sediment is not compacted and has fairly small particles, providing a very porous structure with two dominant textures: sandy (predominant in the basin) and clayey (near the basin's outlet).

From the hydrogeological point of view the Cenozoic sediments, with a thickness of tens of meters, correspond to the more active part of the groundwater dynamics, presenting fast replenishment by direct recharge and high flow velocity to the drainage (Ribeirão da Onça creek). The underlying Guarani Aquifer System is a consolidated sandstone with lower hydraulic conductivity (order of $10^{-5} \mathrm{~m} / \mathrm{s}$ ). Vertical groundwater outflow from the Cenozoic sediments is accounted as the basin contribution to the regional flow system of the Guarani Aquifer System.
The mean annual temperature in the basin is $20.5^{\circ} \mathrm{C}$ based on values obtained from the Climatic Station of CRHEA/EESC/USP (Center for Water Resources and Applied Ecology, Engineering School of São Carlos, University of São Paulo). The Koeppen climate classification for the region indicates that the basin has a humid subtropical climate with a wet summer and a dry winter. The regional average annual precipitation is $1,500 \mathrm{~mm}$. The characterization of precipitation occurrence in the Ribeirão da Onça basin was initiated by Pompêo (1990), who installed three pluviographs at different locations. The data series in the triennium 1985 to 1987 showed that the daily totals were very similar among the three pluviographs, proving the uniformity of rainfall in the basin. 
Altitude $(\mathrm{m})$

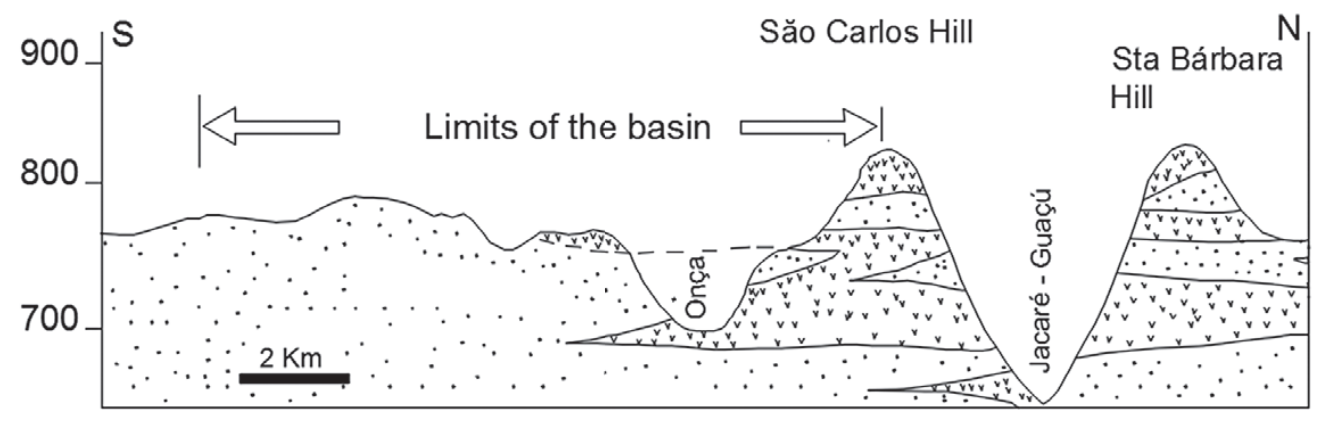

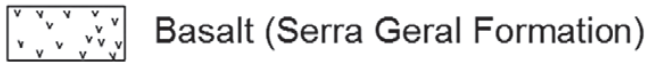 \\ $\because \because \because \therefore$ Sandstone (Botucatu Formation)}

Figure 2 - Geological section through the basin, in SN direction. Modified from Contin Neto (1987).

The Ribeirão da Onça basin is commonly used for agricultural and livestock purposes; paved and industrial areas are not observed. The land vegetation, which was originally cerrado (savanna), now consists of pastures, sugar cane, orange, and eucalyptus plantations, floodplain areas and crops such as soybeans and peanuts (Manzione et al. 2012).

\section{MATERIALS AND METHODS}

A technical device to directly measure the vertical groundwater outflow into a regional groundwater flow system is not available. Consequently, the groundwater outflow has to be determined indirectly as a volumetric water balance in a control volume during a defined period of time. In this study the control volume (Fig. 3) is assumed to be the saturated zone of the Cenozoic sediments, with the upper limit defined by the free water table and the lower limit defined by the interface to the sandstone sediments of the Guarani Aquifer. The water balance is given as

$$
R_{d}=G_{0}+Q_{b}+\Delta S
$$

The input into the control volume is the direct recharge $\left(R_{d}\right)$. Outputs from the system are the base flow $\left(Q_{b}\right)$ and the groundwater outflow $\left(G_{o}\right)$. The groundwater outflow refers to vertical water movement into a lower aquifer, which in this case is the Guarani Aquifer. The variation in stored volume $(\Delta S)$ is obtained from the water level difference between the beginning and the end of the evaluation period. All variables are expressed in terms of rates (e.g., mm/y).

This conceptual model does not consider water losses due to evaporation and evapotranspiration from the free water table. Evaporation is likely to be insignificant since the groundwater level is more than $5.0 \mathrm{~m}$ below ground surface and capillarity

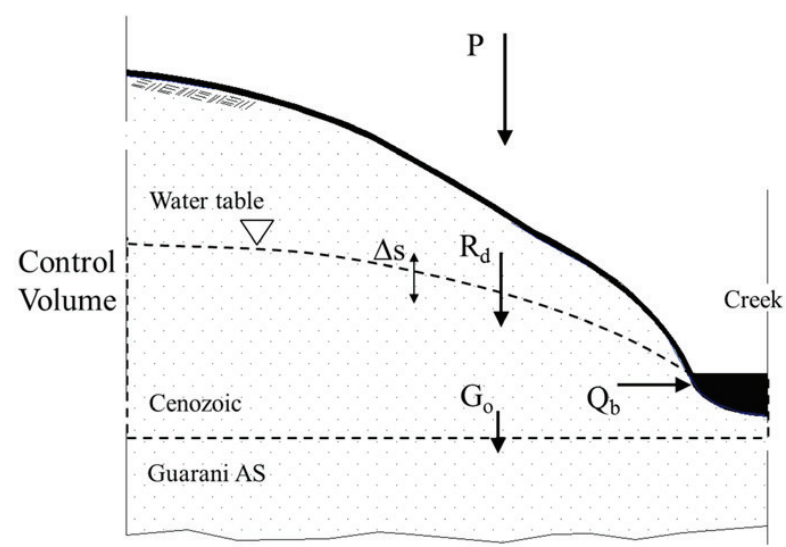

Figure 3 - Conceptual model and control volume for the water balance method $\left(\mathrm{P}=\right.$ precipitation, $\mathrm{R}_{\mathrm{d}}=$ direct recharge, $\Delta s=$ storage variation, $\mathrm{Q}_{\mathrm{b}}=$ base flow, $\mathrm{G}_{0}=$ groundwater outflow). 
effects are insufficient to reach that height in a sandy soil. In the study area there are no wells exploiting groundwater. Upward flow from the GAS is not expected since the watershed is located in a topographic high area. The major advantage of the water balance method is the fact that it depends on easily available data (run off, water levels etc). However, the main limitation is that the recharge evaluation depends on the precision of the other components of the equation (Scanlon et al. 2002).

The direct recharge $\left(R_{d}\right)$ represents the amount of water arriving at the water table from the surface. The direct recharge is calculated using the water table fluctuation method (WTF) (Lerner et al. 1990, Scanlon et al. 2002). This method is based on measurements of water table levels in monitoring wells for a predetermined time period and is estimated as (Healy and Cook 2002, Scanlon et al. 2002)

$$
R_{d}=S_{y} \frac{d h}{d t}=S_{y} \frac{\Delta h}{\Delta t}
$$

where $S_{y}$ is the specific yield, $h$ is the groundwater level, and $t$ is the time. The $\Delta h$ variation is the difference between the peak of the upslope curve and the lowest point of the antecedent recession curve extrapolated to the time that the peak occurred (Fig. 4). The extrapolated recession curve is the hydrographic trajectory of the monitoring well in the absence of any water level rise and represents the continued losses $\left(Q_{b}\right.$ and $\left.G_{o}\right)$ during the recharge period. Exponential equations are used for this extrapolation as is usually applied for surface water hydrographs (Singh and Stall 1971).

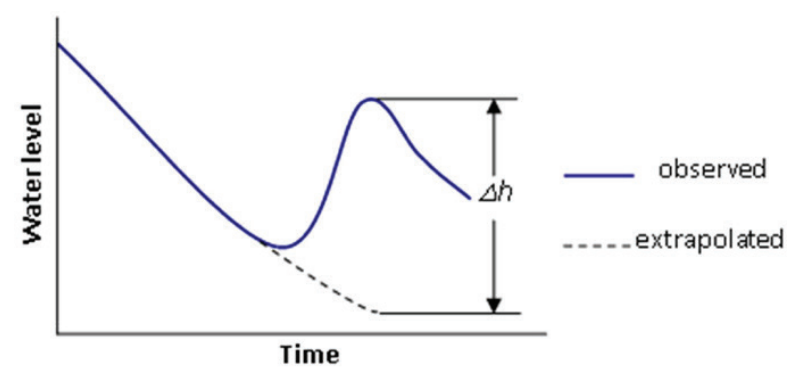

Figure 4 - Water level recession curve extrapolation. $\Delta h$ is the rise due to the recharge in the observation period.
The underground storage variation $(\triangle S)$ in an unconfined aquifer during the monitoring period is estimated as:

$$
\Delta S=\Delta h_{b} \cdot S_{y}
$$

where $\Delta h_{b}$ is the water table variation during the period of the water balance calculation.

For this study nine wells $(05,08,13,14,15,16$, 17, 18 and 19) were used, as shown in Figure 5. These wells are representative for the different land uses in the basin. Ignored wells are located outside the basin or did not have continuous data for the study period. In dry years the water table fell below the well bottom and the data series was not continuous, invalidating any evaluation. These monitoring wells are too shallow and should have been drilled deeper.

Both equation 2 and 3 depend on the specific yield $\left(S_{y}\right)$, which corresponds to the drainable porosity of the medium. In order to increase the reliability of the recharge estimates, undisturbed soil samples were collected (Fig. 5) at depths that correspond to the water table variation. The undisturbed samples were analyzed using the Haines funnel technique (Haines 1930), in which the soil is submitted to a fixed water tension. The principles and equations upon which the equipment is based, are described by Libardi (1995). Three samples were tested for each location and depth (Gomes 2008). In addition to the specific yield, which is related to macroporosity, the total porosity was also determined weighing the oven dried samples. Disturbed soil samples were used to determine particle size and to construct the granulometric curves to characterize the soil.

Base flow $\left(Q_{b}\right)$ was measured twice a month directly in the control section using a flowmeter (Model MLN-7, JCTM). The discharge was quantified using the midsection method (Turnipseed and Sauer 2010). A runoff model was also applied to the study area. The basin physical parameters required for the IPHS-1 code (Collischonn and Tucci 2001) were determined for a maximum flow discharge of $2.5 \mathrm{~m}^{3} / \mathrm{s}$. This was the maximum value 


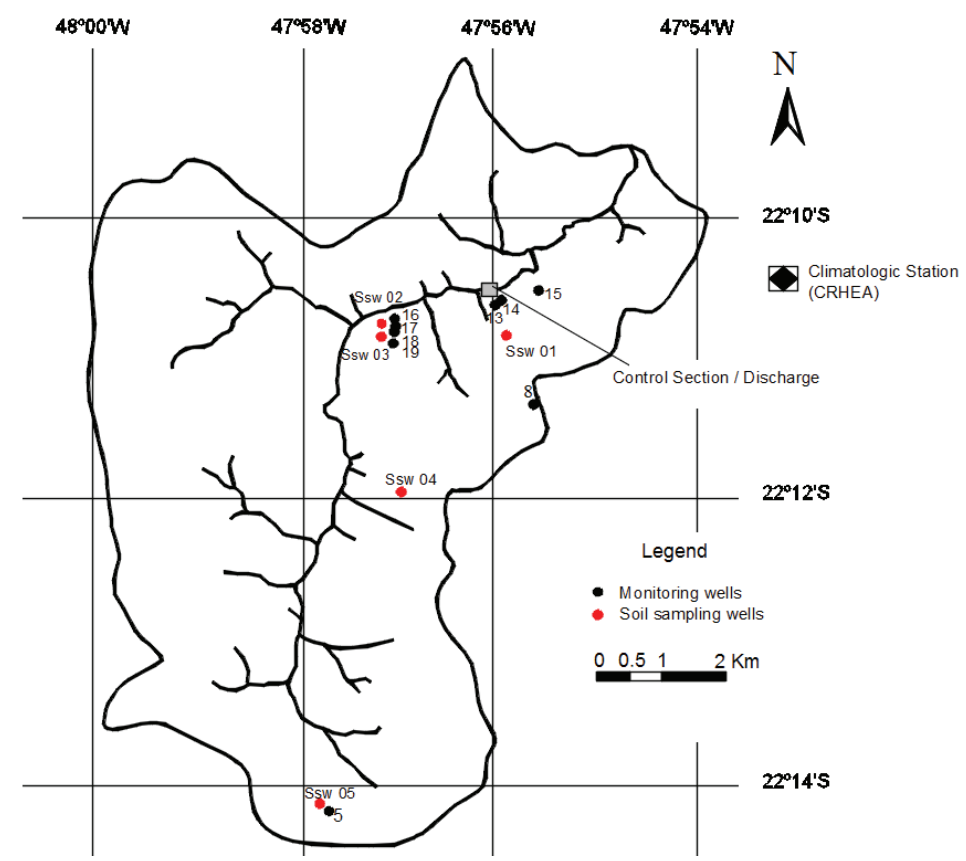

Figure 5 - Location of monitoring and soil sampling wells in the watershed.

observed at the control section according to studies by Contin Neto (1987), Pompêo (1990), Arantes (2003) and Barreto (2005).

\section{RESULTS}

In this section meteorological data, water levels in the monitored wells and base flow obtained in the Ribeirão da Onça basin for the period between September 2004 and September 2007 are presented. Results of the collected undisturbed soil samples and the values of the specific yield obtained in laboratory analyses are shown. Subsequently, the direct recharge values and variation in storage are evaluated, both of which are dependent on the specific yield. The evaluation is concluded with the groundwater outflow as a result of the water balance in the saturated zone, separated into the three hydrological years.

\section{Preciptatation}

The meteorological data were obtained from the meteorological station located in CRHEA by direct readings of a Ville de Paris rain gauge and an automatic station. The historical annual rainfall average (data collected between 1971 and 2007) was $1527 \mathrm{~mm}$. During the present study period the lowest annual rainfall occurred in $2006(1367 \mathrm{~mm})$; this value is $11 \%$ lower than the historical average. In 2004 , the rainfall was $1619 \mathrm{~mm}$, or $6 \%$ above average. In 2007, the rainfall of $1503 \mathrm{~mm}$ was close to the historical average. The rainy periods correspond to the months from October to March, and the dry periods correspond to the months from April to September.

\section{VARIATIONS IN WATER LEVEL}

Water table fluctuations were monitored for the hydrological years from September 2004 to August 2005, September 2005 to August 2006 and September 2006 to August 2007.

The monitoring data indicated that rainfall events during the period from November to March (with a peak in January) resulted in a rise in water levels in the wells, with maximum values generally in February. Therefore, we can consider that the period of recharge corresponds to the months 
from December to March. Starting in April, there is a decrease in the values of hydraulic head associated with the onset of the dry season for the year. Small rainfall amounts rarely cause sensitive responses in levels, as can be seen during the period from April to August, when there is a significant decrease in rainfall. The described behavior occurs when the annual precipitation value is near the average. In the hydrological year $2005 / 2006$, the total precipitation was $11 \%$ below the historical average, leading to little change in the water table. For the rainy seasons in 2004/2005 and 2006/2007, the water table rise occurred between December and March, with partial rainfalls of $1244 \mathrm{~mm}$ and $1323 \mathrm{~mm}$, respectively. In 2005/2006, there was a very subtle rise in the period between January and April due to a low rainfall of $1017 \mathrm{~mm}$ (18\% lower than in $2004 / 2005$ and $30 \%$ lower than in 2006/2007).

\section{MAP OF HYDRAULIC HEADS}

With water level information obtained from all 21 monitoring wells available in the basin, it was possible to generate a map (Fig. 6) of hydraulic heads for the dry and rainy seasons in the basin in which the wells are located. The dates chosen for the map were February 15, 2005 with the higher water levels in the wet season, and December 15, 2006 with the lowest values at the end of the dry period. Although the number of monitoring wells is limited, especially at the highest points of the basin, the generated map appears reliable and enables the comprehension of the flow system. Note that the hydraulic head curves for the two periods almost coincide in the region near the stream and separate near the divide of the basin, and that the variations in water levels are higher in this region. The potentiometric map shows the flow directions, indicating that the groundwater divide is very close to the surface water divide in this basin and demonstrates the influence of the surface drainage. Only one side of the watershed was monitored and evaluated. Due to monitoring logistic (e.g., large distances to be traversed) the wells were installed on only one side of the basin. Since the land uses on both sides of the watershed are similar, the monitored half is considered to be representative. All the evaluated values for the water balance are normalized by the respective areas in order to get consistent rates [mm/a].

SPECIFIC YIELD $\left(\mathrm{S}_{\mathrm{Y}}\right)$

The specific yield is approximately equal to the storage coefficient, which is generally less than the porosity of the medium. The soil samples, collected at depths that correspond to the range of variations in the groundwater level, were used to determine the specific yield. Disturbed samples were used to characterize particle size. Rows of pebbles were found during the collection of samples, confirming the characteristics of Cenozoic sediments described by Bortolucci (1983).

The average specific yield ranged from $8.5 \%$ to $15.9 \%$ according to the spatial distribution of the sampling points (see Fig. 4). It was verified that this value increased as a function of depth in some of the soil sampling wells ( $\mathrm{Ssw}$ 02, 03 and 05). However, this behavior was not observed elsewhere (Ssw 01 and 04). Values of the specific yields of samples at various depths were condensed and are presented in Table I (Gomes 2008). The collected samples presented an overall average specific yield of $12.0 \%$ and a standard deviation of $2.9 \%$, maintaining the spatial uncertainty of this parameter. In addition to the specific yield, which is related to macroporosity, the soil microporosity was also determined using an oven to dry the samples. Soil granulometry analysis was performed for different collection points, and granulometric curves were plotted to characterize the soil. From the average granulometric composition of the tested samples, the fine sand percentage value $(65 \%)$ is the highest, followed by the medium sand value $(20 \%)$. 


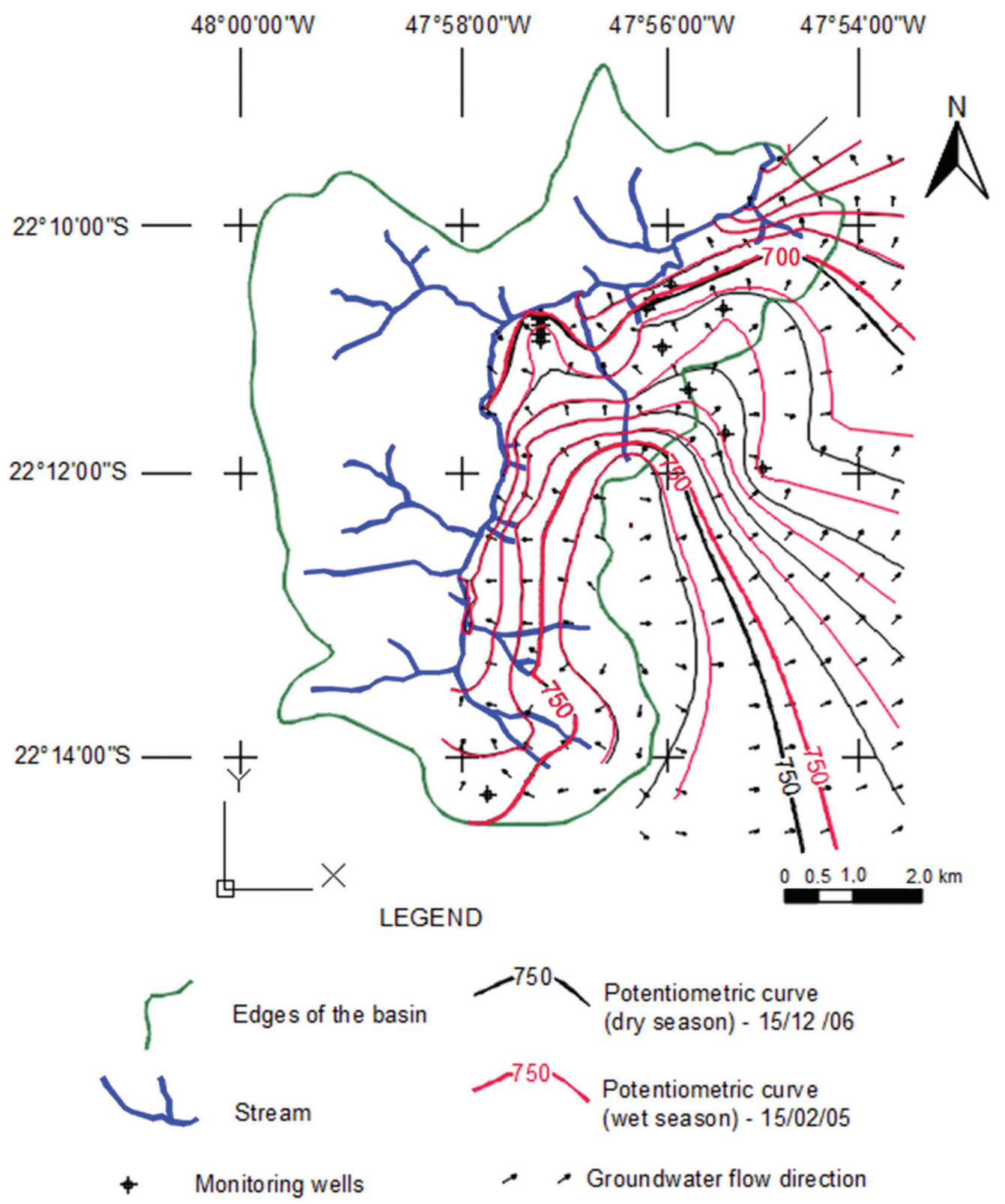

Figure 6 - Hydraulic head map of the basin for the days 02/15/2005 (wet season) and 12/15/2006 (dry season).

\section{DIRECT RECHARGE}

The direct recharge is equivalent to the amount of water that percolated below the root zone and was calculated using the water table fluctuation method (WTF) (Lerner et al. 1990, Scanlon et al. 2002). Figure 7 shows the method applied to the water level variations in well 18, located in a meadow in the Ribeirão da Onça basin.
This well is $29 \mathrm{~m}$ deep with 4-inches casing. The well is screened between $21 \mathrm{~m}$ and $29 \mathrm{~m}$ depth. As shown in Figure 7, the groundwater level varies approximately between $10 \mathrm{~m}$ and $17 \mathrm{~m}$ below surface.

Water level fluctuations were evaluated for the hydrological years from September 2004 to August 2005, September 2005 to August 2006 and September 
TABLE I

Specific yield of samples collected at different points and depths (Gomes 2008).

\begin{tabular}{|c|c|c|c|c|c|c|c|c|c|}
\hline \multicolumn{10}{|c|}{ Soil Sampling Wells (Ssw) } \\
\hline \multicolumn{2}{|c|}{ Ssw 01} & \multicolumn{2}{|c|}{ Ssw 02} & \multicolumn{2}{|c|}{ Ssw 03} & \multicolumn{2}{|c|}{ Ssw 04} & \multicolumn{2}{|c|}{ Ssw 05} \\
\hline $\operatorname{Depth}(\mathrm{m})$ & Sy & $\operatorname{Depth}(\mathrm{m})$ & Sy & $\operatorname{Depth}(\mathrm{m})$ & Sy & $\operatorname{Depth}(\mathrm{m})$ & Sy & $\operatorname{Depth}(\mathrm{m})$ & Sy \\
\hline 13.0 & $8.7 \%$ & 3.0 & $15.4 \%$ & 6.1 & $12.4 \%$ & 14.8 & $9.6 \%$ & 4.4 & $16.8 \%$ \\
\hline 14.0 & $7.8 \%$ & 4.0 & $15.2 \%$ & 7.1 & $12.4 \%$ & 16.0 & $10.4 \%$ & 5.4 & $15.7 \%$ \\
\hline 15.8 & $9.0 \%$ & 4.5 & $14.7 \%$ & 8.4 & $8.9 \%$ & 16.9 & $11.1 \%$ & 6.0 & $15.1 \%$ \\
\hline- & - & - & - & 9.3 & $10.4 \%$ & 18.1 & $12.7 \%$ & - & - \\
\hline- & - & - & -- & - & - & 19.1 & $9.0 \%$ & - & - \\
\hline Average & $8.5 \%$ & Average & $15.1 \%$ & Average & $11.3 \%$ & Average & $10.6 \%$ & Average & $15.9 \%$ \\
\hline Deviation & $0.6 \%$ & Deviation & $0.4 \%$ & Deviation & $1.7 \%$ & Deviation & $1.4 \%$ & Deviation & $0.9 \%$ \\
\hline
\end{tabular}

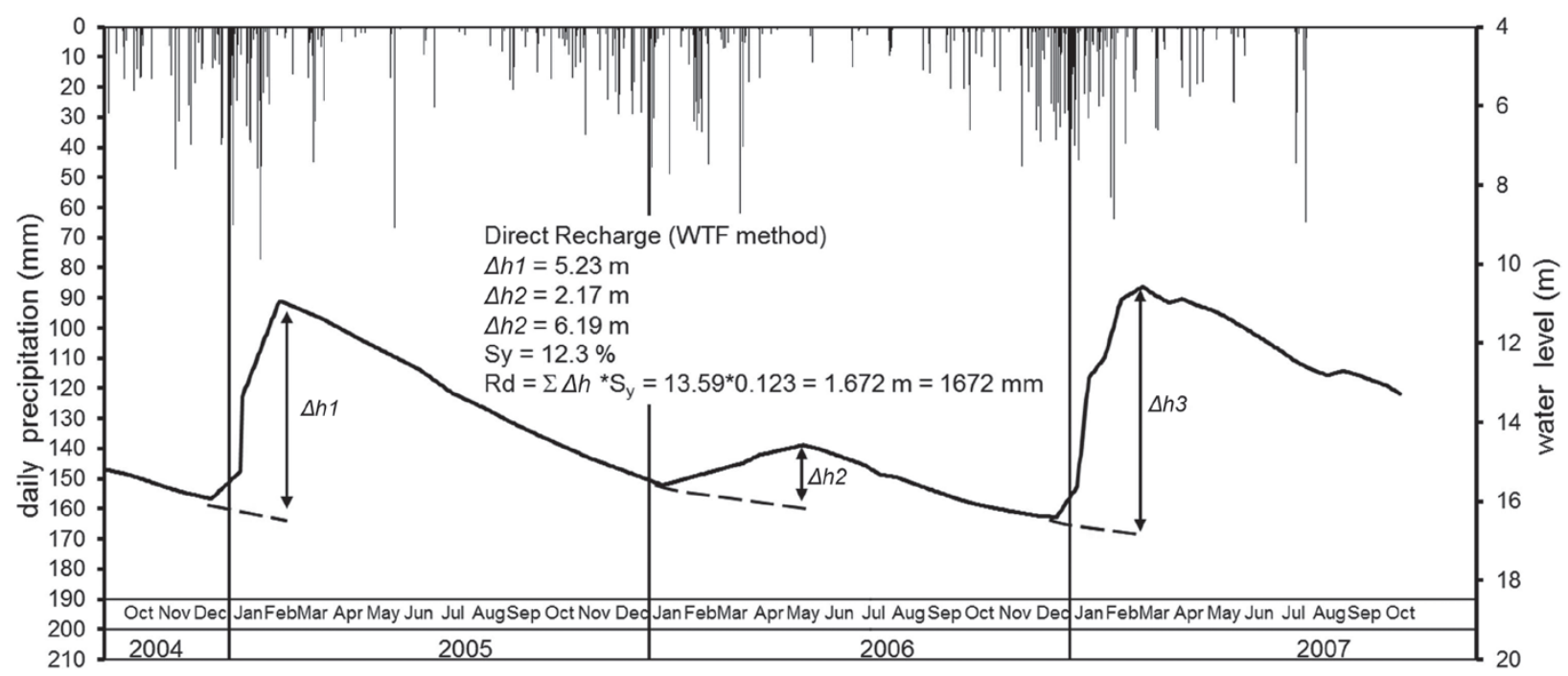

Figure 7 - WTF method applied to the well 18 during the study period.

2006 to August 2007. Table II shows the values of the direct recharge calculated at each monitoring well for each hydrological year. The values ranged from 57 $\mathrm{mm}$ for well 15 in the 2005-2006 hydrologic year to $845 \mathrm{~mm}$ for well 18 in the 2006-2007 hydrologic year. Mean water depth was defined as the average value of maximum and minimum water depth observed at each hydrological year. Specific yield for each well was determined according to the distance to the soil sampling wells and to the mean water depth.

In order to estimate an average recharge value for the whole basin, an area of influence for each well was estimated. It was observed that the direct recharge evaluated for each well is influenced by the mean water depth. Since the mean water depth increases with growing distance perpendicular to the drainage axis, the distance to a creek was used to define the areas of influence. The influence areas, indicated in Table II, were used as weighing factors leading to a weighted average of the direct recharge in the basin. Direct recharge as a percentage of rainfall was estimated as $32 \%, 14 \%$ and $38 \%$, for the hydrologic periods between 2004 and 2007, 
TABLE II

Well details and direct recharge estimated for the hydrologic years between 2004 and 2007.

\begin{tabular}{cccccccc}
\hline $\begin{array}{c}\text { Well } \\
\text { number }\end{array}$ & $\begin{array}{c}\text { Well } \\
\text { depth (m) }\end{array}$ & $\begin{array}{c}\text { Mean water } \\
\text { depth (m) }\end{array}$ & $\begin{array}{c}\text { Specific } \\
\text { yield (\%) }\end{array}$ & $\begin{array}{c}\text { Influence } \\
\text { area (\%) }\end{array}$ & $\begin{array}{c}\text { 2004 - 2005 } \\
\text { Rainfall } \\
\mathbf{1 4 4 4} \mathbf{~ m m}\end{array}$ & $\begin{array}{c}\mathbf{2 0 0 5} \mathbf{- 2 0 0 6} \\
\text { Rainfall } \\
\mathbf{1 2 0 3} \mathbf{~ m m}\end{array}$ & $\begin{array}{c}\mathbf{2 0 0 6}-\mathbf{2 0 0 7} \\
\text { Rainfall } \\
\mathbf{1 7 1 1} \mathbf{~ m m}\end{array}$ \\
\hline 16 & 22.0 & 5.2 & 15.1 & 10.5 & 293 & 79 & 482 \\
5 & 50.0 & 6.6 & 15.9 & 10.5 & 319 & 180 & 524 \\
14 & & 6.6 & 8.5 & 10.5 & 298 & 122 & 311 \\
15 & & 7.9 & 8.5 & 6.8 & 242 & 57 & 202 \\
13 & & 9.8 & 8.5 & 6.8 & 320 & 101 & 324 \\
17 & 26.0 & 11.0 & 12.3 & 6.8 & 464 & 167 & 579 \\
\hline
\end{tabular}

respectively. Barreto (2005) estimated the direct recharge as $29 \%$ of the total precipitation $(1410 \mathrm{~mm})$ during the period of his assessment (January to December, 2005) in the same basin.

\section{CHANGE IN STORAGE}

The change in underground storage in an unconfined aquifer drained by a watercourse is equal to the change in water volume that occurs when the level of the aquifer varies in relation to the previous level. Figure 8 shows the determination of the storage variation specified for well 18. It is notable that there was a sharp drop in the volume of water stored during the 2005/2006 season due to the lower rainfall during this period. The rainfall amount decreased by $17 \%$ compared to the previous period, resulting in a significant reduction in aquifer storage $(-130 \mathrm{~mm})$. However, during the $2006 / 2007$ period, there was an increase in rainfall ( $42 \%$ increase compared to the previous period), resulting in a recovery of the volume stored in the basin $(176 \mathrm{~mm})$. For the other wells the behavior is similar.

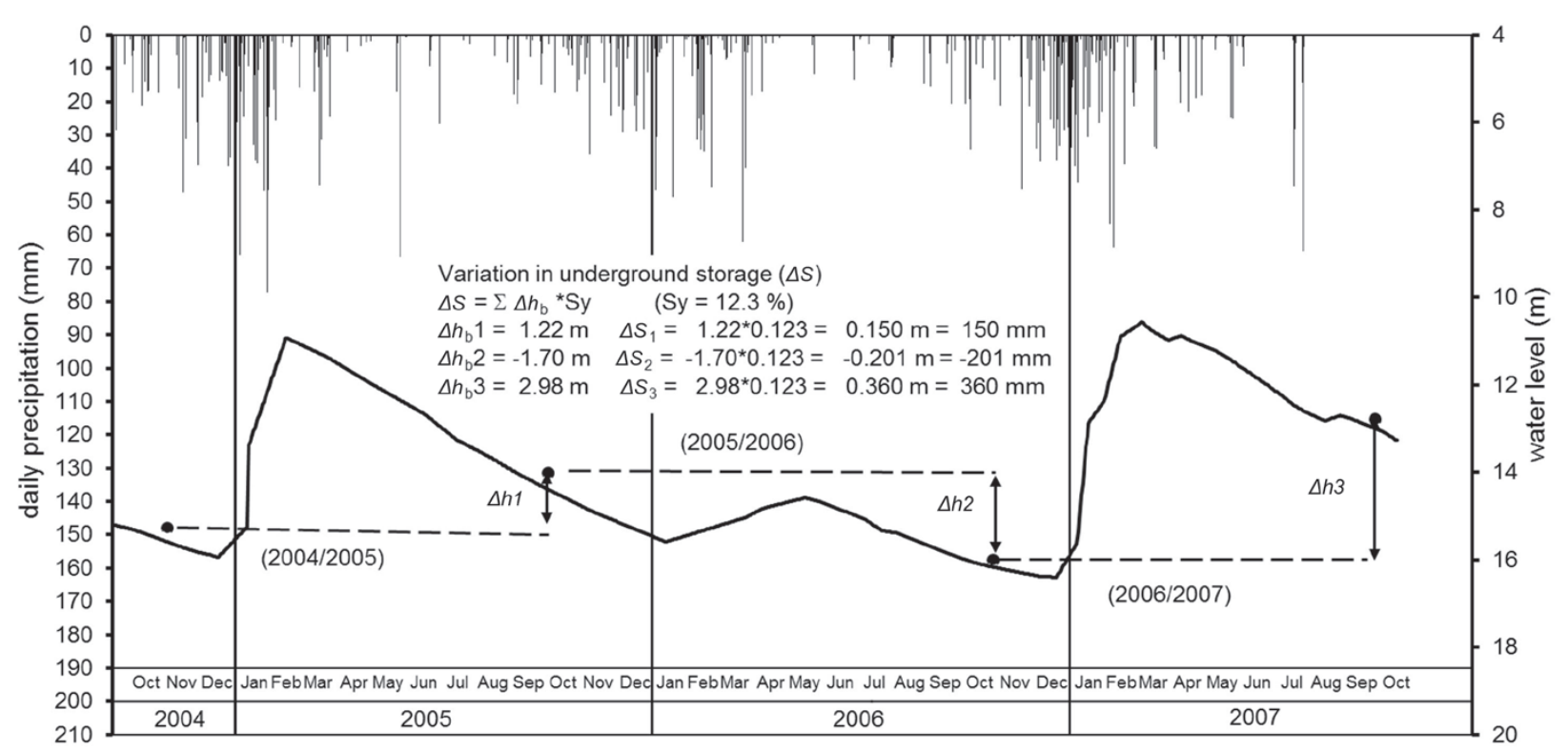

Figure 8 - Groundwater storage in well 18, calculated for each hydrological year. 


\section{BASE FLOW}

The base flow and surface outflow were estimated using a series of rainfall totals in the basin and a series of discharges. The base flow was determined from a rain-flow model applied to the study area (Gomes 2008). The parameters used for generating flows with the IPHS 1 software
(Collischonn and Tucci 2001) were determined so that the maximum flows were less than $2.5 \mathrm{~m}^{3} / \mathrm{s}$. The model was calibrated based on the discharges measured twice a month, with a flowmeter in the control section. The maximum flow was calculated as $2.1 \mathrm{~m}^{3} / \mathrm{s}$. The hydrographs of total and base flows are shown in Figure 9.

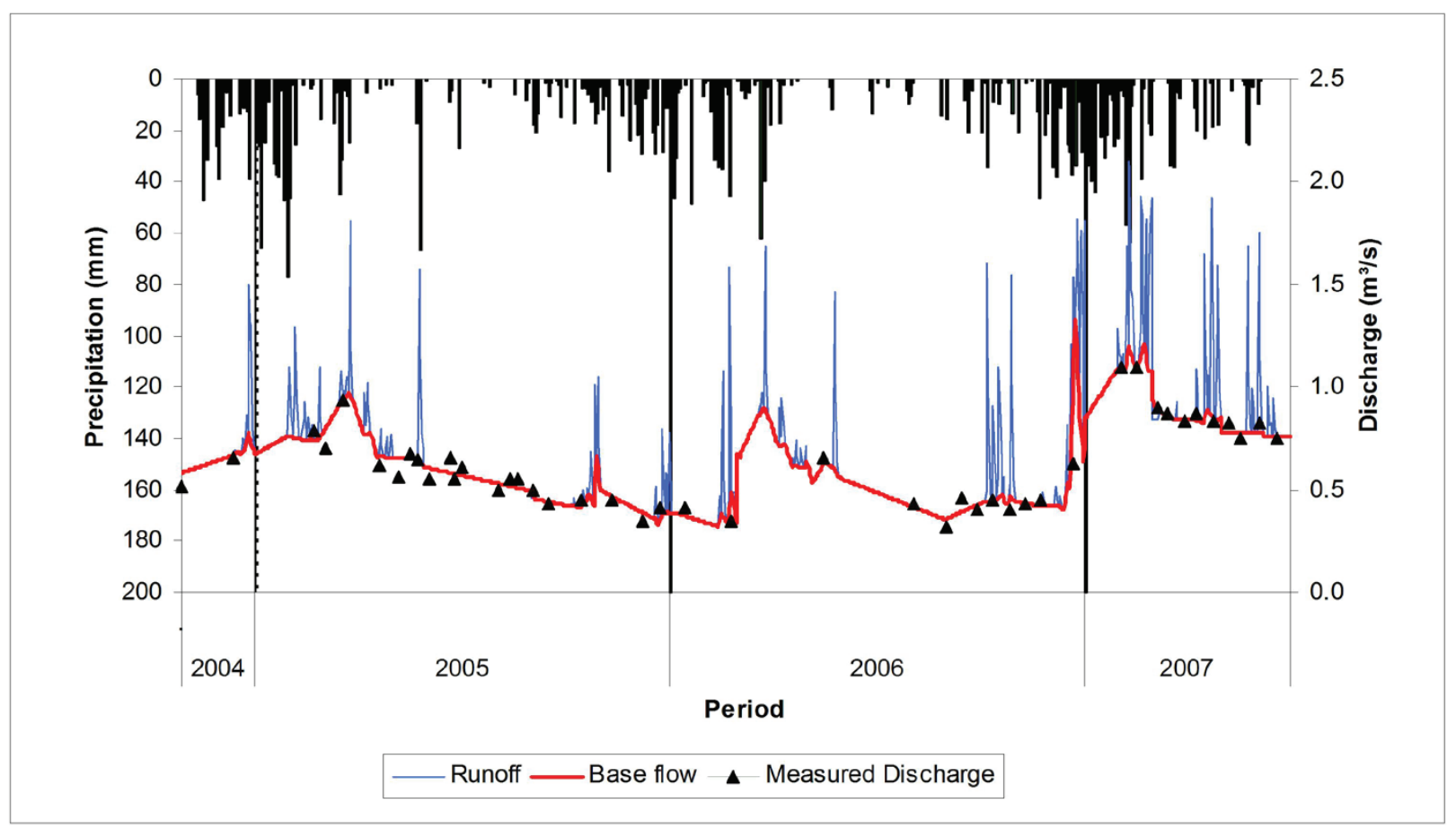

Figure 9 - Hydrograph generated by the IPHS1 model in comparison to discharges measured at the control section.

The base flow presents a well-characterized seasonal behavior as it rises during the rainy season from October to March, shows depletion in April, and reaches minimum values in September. Base flow values closely mimic the rainfall value for the period, ranging between $24 \%$ and $26 \%$ of the precipitation. This small variation shows the constancy of the general conditions of the basin during this monitoring period. Surface flow (runoff) during rain events shows a variation of $1.2 \%$ to $3.3 \%$ of the precipitation. These values are compatible with $1.5 \%$ of the rainfall in the basin, as obtained by Contin Neto (1987). The low values result from sandy soils, flat relief and low runoff in the basin.

\section{Water BALANCE IN THE SATURATED ZoNE}

The water balance methodology assumed the saturated soil region in the basin as the control volume. Following the principle of continuity, the system input is represented by direct recharge $\left(R_{d}\right)$, whereas the system output is given by the base flow $\left(Q_{b}\right)$ and groundwater outflow $\left(G_{o}\right)$. The variation of the underground stored volume $(\Delta S)$ is determined from the variation of the level in the monitoring wells during the hydrological year.

The model considered lateral contribution to be zero because of the location of the basin at high topographic elevation in the region, with the 
groundwater divide coincident with the surface water divide. The following equation represents the water balance:

$$
G_{0}=R_{d}-Q_{b}-\Delta S
$$

Table III shows the components of the water balance calculated for the three periods. During the 2004/2005 period, the amount of the direct recharge was $461 \mathrm{~mm}$, i.e., $32 \%$ of the total precipitation $(1444 \mathrm{~mm})$. These values are close to those found by Barreto (2005) in this basin. In that study, the author presented a direct recharge value of $29 \%$ of the precipitation. During $2005 / 2006$, there was a $17 \%$ reduction in rainfall compared to the previous period. In this period, the recharge was $14 \%(164 \mathrm{~mm})$ of the $1203 \mathrm{~mm}$ of rainfall. The rainfall amount during the 2006/2007 hydrologic year was $1711 \mathrm{~mm}$, the highest value in the study period. The direct recharge of $656 \mathrm{~mm}$ corresponded to $38 \%$ of the $1711 \mathrm{~mm}$ of rainfall. In the 2004/2005 and $2006 / 2007$ periods, the storage was positive, with values of $66 \mathrm{~mm}$ and $176 \mathrm{~mm}$, respectively. The storage was negative $(-130 \mathrm{~mm})$ during the $2005 / 2006$ season due to low precipitation. The groundwater outflow ranged from $5 \mathrm{~mm}$ to $41 \mathrm{~mm}$, equivalent to $0.4 \%$ to $2.4 \%$ of the total precipitation during the study period.

TABLE III

Average water balance in the basin for the hydrologic years between 2004 and 2007.

\begin{tabular}{lccc}
\hline & $\mathbf{2 0 0 4} \mathbf{- 2 0 0 5}$ & $\mathbf{2 0 0 5} \mathbf{- 2 0 0 6}$ & $\mathbf{2 0 0 6}-\mathbf{2 0 0 7}$ \\
\hline Precipitation (mm) & 1444 & 1203 & 1711 \\
Direct recharge (mm) & 461 & 164 & 656 \\
Base outflow (mm) & 380 & 289 & 438 \\
Storage (mm) & 66 & -130 & 176 \\
GWater outflow (mm) & 15 & 5 & 41 \\
GWater outflow / Precipitation (\%) & 1.04 & 0.42 & 2.40 \\
\hline
\end{tabular}

\section{DISCUSSION}

The objective of this study was to estimate the groundwater recharge in the Ribeirão da Onça basin using the water balance method in the saturated zone of soil, supported by hydrogeological monitoring data. Furthermore the outflow to the regional GAS was to be quantified. The following variables of the hydrological cycle were monitored and/or determined: precipitation, groundwater level, total and base level stream flow. Aquifer level data were used to estimate direct recharge and changes in groundwater storage volumes.

The average specific yield $\left(S_{y}\right)$ determined for the soil was $12.2 \%$, with a standard deviation of $2.9 \%$. The values determined in the laboratory for undisturbed soil samples were shown to be consistent with those in the literature (Healy and
Cook 2002), which range between $10 \%$ and $28 \%$ for the same textural class. Using the WTF method in the Ribeirão da Onça basin, the direct recharge for the 2004 to 2007 period ranged between $164 \mathrm{~mm}$ and $656 \mathrm{~mm}$, i.e., $14 \%$ to $38 \%$ of the rainfall during the respective periods. The variation in storage was negative $(-130 \mathrm{~mm})$ during the hydrologic year (2005-2006) with less precipitation. This was a very dry period; the precipitation was below the long term average, resulting in a significant drainage of the aquifer. The base flow estimated by a hydrologic model was between $24 \%$ and $26 \%$ of the total precipitation in the Ribeirão da Onça basin during the study period. In previous studies, Barreto (2005) estimated the base flow to be $30 \%$ of the precipitation. Runoff ranged from $1.2 \%$ to $3.3 \%$ of the total precipitation, being consistent with values 
obtained from previous studies conducted in the basin (Contin Neto 1987, Pompêo 1990, Barreto 2005). Using the water balance in the saturated zone, the groundwater outflow to the regional flow system during the period from 2004 to 2007 was estimated to be lower than $3.0 \%$ of the total precipitation. The values show that the recharge rates of the Guarani Aquifer System (GAS) are actually low in this region.

The obtained results indicate that the GAS in the study area is filled with water. Despite high values of direct recharge (up to $656 \mathrm{~mm} / \mathrm{year}$ in 2006/2007), this water cannot be stored in the GAS due to the absence of storage. Consequently, the recharged water is removed from the recharge area in the form of surface drainage, reaching annual base flow values between 289 and $438 \mathrm{~mm}$ /year. The difference between the direct recharge and base flow observed during the study period reflects mainly the variation in groundwater levels (storage variation) in Cenozoic sediments that overlie the aquifer. From the viewpoint of sustainable exploitation, it is expected that, with increased uptake through pumping wells, the aquifer storage created will be filled by recharge water, causing a reduction in the base flow.

The findings of this study are based on annual values of surface water flow that were calculated by a runoff model calibrated for the basin. This variable is the primary source of uncertainty in the water balance and should be measured continuously, reducing the uncertainty of the results. The estimated groundwater outflow through the lower boundary of the control volume is in the range of measurement errors of the monitored variables. The obtained recharge values have to be seen as expected magnitudes and not as exact numbers. The use of complementary techniques (e.g., hydrogeochemical, isotopic, temperature measurement) is necessary and should be tested in the future. However, long term water level monitoring is relatively less expensive and has been preferred for economic reasons. The continued monitoring of hydrological variables in the Ribeirão da Onça basin is of great importance for future studies. Such studies should provide more precise data aiming at a better understanding of the mechanisms governing the Guarani Aquifer System behavior in its outcrop areas.

\section{ACKNOWLEDGMENTS}

The authors acknowledge the Coordenação de Aperfeiçoamento de Pessoal de Nível Superior (CAPES) support for the scholarship and the Conselho Nacional de Desenvolvimento Científico e Tecnológico (CNPq) for financial support for the project. We very much appreciated the valuable suggestions by the reviewers. The comments certainly contributed towards improving the quality of the paper.

\section{RESUMO}

A contribuição da recarga para sistemas regionais de fluxo de água subterrânea é uma informação essencial requerida para estabelecer o gerenciamento sustentável de recursos hídricos. O objetivo deste trabalho foi determinar o escoamento de água subterrânea na Bacia do Ribeirão da Onça usando um modelo de balanço hídrico da zona saturada do subsolo. A bacia está localizada em uma área de afloramento do Sistema Aquífero Guarani (SAG). O método do balanço hídrico envolveu a determinação de valores de recarga direta, variação do armazenamento de água subterrânea e escoamento de base. A recarga direta foi determinada pelo método de flutuação da superfície livre (WTF, em inglês). $\mathrm{O}$ escoamento de base foi calculado pelo método de separação da hidrógrafa, que foi gerada por um modelo chuva-vazão, com suporte de medições quinzenais de vazão na seção de controle. Amostras indeformadas de solo foram coletadas em profundidades correspondentes à zona de flutuação do nível freático, para determinação do rendimento específico do solo (porosidade drenável). Os balanços hídricos na zona saturada foram calculados para os anos hidrológicos de fevereiro de 2004 a janeiro 
de 2007. A recarga direta variou de $14,0 \%$ a $38,0 \%$ e o escoamento subterrâneo de água variou de $0,4 \%$ a 2,4\% da respectiva precipitação durante o mesmo período.

Palavras-chave: Água subterrânea, monitoramento, recarga, rendimento específico, WTF.

\section{REFERENCES}

ARANTES EJ. 2003. Emprego de Infiltrômetros na Caracterização da Interação Rio e Aqüífero. Dissertação (Mestrado). Escola de Engenharia de São Carlos, Universidade de São Paulo, São Carlos. (Unpublished).

ARAÚJO LM, FrANÇAAB AND POTTER PE. 1999. Hydrogeology of the Mercosul aquifer system in the Paraná and ChacoParaná basins, South America, and comparison with the Navajo-Nugget aquifer system, USA. Hydrogeol J 7(3): 313-336.

ARnOlD JG, MutTiah RS, SRINIVASAN R AND AlLEN PM. 2000. Regional estimation of base flow and groundwater recharge in the Upper Mississippi river basin. J Hydrol 227(1-4): 21-40.

BARRETO CEAG. 2005. Balanço hídrico em zona de afloramento do Sistema Aqüífero Guarani a partir de monitoramento hidrogeológico. Dissertação (Mestrado). Escola de Engenharia de São Carlos, Universidade de São Paulo, São Carlos. (Unpublished).

Beekman HE, Gieske A and Selaolo ET. 1996. GRES Groundwater Recharge Studies in Botswana 1987-1996. Botswana J Earth Sci III: 1-17.

BORTOLUCCI AA. 1983. Caracterização Geológico-Geotécnica da região urbana de São Carlos-SP, a partir de sondagens de simples reconhecimento. Dissertação (Mestrado). Escola de Engenharia de São Carlos, Universidade de São Paulo, São Carlos. (Unpublished).

COLLischonN W AND TUCCI CEM. 2001. Simulação hidrológica de grandes bacias. Rev Bras Rec Híd 6(2): 95-118.

Contin Neto D. 1987. Balanço Hídrico em Bacia Hidrográfica situada em Região de Recarga do Aqüífero Botucatu. Tese de Doutorado. Escola de Engenharia de São Carlos, Universidade de São Paulo, São Carlos.

DE VRIES JJ AND SIMMERS I. 2002. Groundwater recharge: an overview of processes and challenges. Hydrogeol J 10: 5-17.

Dewandel B, Perrin J, Ahmed S, Aulong S, Hrkal Z, LACHASSAGNE P, SAMAD M AND MASSUEL S. 2010. Development of a tool for managing groundwater resources in semi-arid hard rock regions: application to a rural watershed in South India. Hydrol Process 24: 2784-2797.

FEtTER CW. 1994. Applied Hydrogeology, Prentice-Hall, EUA, 598 p.

Foster S, Kemper K AND Garduno H. 2004. Brazil, Paraguay, Uruguay, Argentina: the Guarani aquifer initiative for transboundary groundwater management. GW MATE case profile collection; no. 9. Washington, DC: World Bank.
GOMES LH. 2008. Determinação da recarga profunda na baciapiloto do Ribeirão da Onça em zona de afloramento do Sistema Aqüífero Guarani a partir de balanço hídrico em zona saturada. Dissertação de Mestrado - Escola de Engenharia de São Carlos, Universidade de São Paulo, São Carlos. (Unpublished).

Gómez A, RodríguEZ L AND VIVES L. 2010. The Guarani Aquifer System: estimation of recharge along the Uruguay-Brazil border. Hydrogeol J 18(7): 1667-1684.

HAINES WB. 1930. Studies in the physical properties of soil: $\mathrm{V}$. The hysteresis effect in capillary properties, and the modes of moisture distribution associated therewith. J Agric Sci 20: 97-116.

HEALY RW. 2010. Estimating groundwater recharge, Cambridge Univ. Press, $245 \mathrm{p}$.

HEALY RW AND COOK PG. 2002. Using groundwater levels to estimate recharge. Hydrogeol J 10: 91-109.

HiRATA R AND CONICELli BP. 2012. Groundwater resources in Brazil: a review of possible impacts caused by climate change. An Acad Bras Cienc 84: 297-312.

Hugman R, Stigter TY, Monteiro JP AND Nunes L. 2012. Influence of aquifer properties and the spatial and temporal distribution of recharge and abstraction on sustainable yields in semi-arid regions. Hydrol Process 26: 2791-2801.

KinZELbACH W (ORG). 2002. A Survey of Methods for Groundwater Recharge in Arid and Semi-Arid Regions. Early Warning and Assessment Report Series, UNEP/ DEWA/RS.02/2. United Nations Environment Programme, Nairobe, Kenia.

LERNER DN, ISSAR AS AND SIMMERS I. 1990. Groundwater recharge: a guide to understanding and estimating natural recharge. International Contributions to Hydrogeology, Vol. 8. Int. Association of Hydrogeologists, Verlag Heinz Heise.

LIBARDI PL. 1995. Dinâmica da água no solo. $2^{\text {a }}$ ed., Piracicaba, SP, $497 \mathrm{p}$.

MANZIONE RL, Wendland E AND TANIKAWA DH. 2012. Stochastic simulation of time-series models combined with geostatistics to predict water-table scenarios in a Guarani Aquifer System outcrop area, Brazil. Hydrogeol J 20(7): 1239-1249.

Maréchal JC, Dewandel B, Ahmed S, Galeazzi L and ZAIDI FK. 2006. Combined estimation of specific yield and natural recharge in a semi-arid groundwater basin with irrigated agriculture. J Hydrol 329(1-2): 281-293.

Moon SK, Woo NC AND LEE KS. 2004. Statistical analysis of hydrographs and water-table fluctuation to estimate groundwater recharge. J Hydrol 292(1-4): 198-209.

Naeem S, O'Neill RV, Paruelo J, Raskin RG, Sutton P AND VAN DEN BELT M. 1997. The value of the world's ecosystem services and natural capital. Nature 387(6630): 253-260

POMPÊo CA. 1990. Balanço Hídrico da Zona Não-Saturada do Solo na Bacia do Ribeirão do Onça (SP). Tese de Doutorado. Escola de Engenharia de São Carlos, Universidade de São Paulo, São Carlos. 
RABelo JL AND WendLAND E. 2009. Assessment of groundwater recharge and water fluxes of the Guarani Aquifer System, Brazil. Hydrogeol J 17: 1733-1748.

RAudsepp-HeArne C, Peterson GD And BennetT EM. 2010. Ecosystem service bundles for analyzing tradeoffs in diverse landscapes. Proceedings of the National Academy of Sciences of the United States of America 107(11): $5242-5247$.

SANFORD W. 2002. Recharge and groundwater: an overview. Hydrogeol J 10: 110-120.

SCANLON BR, HeAly RW AND COOK PG. 2002. Choosing appropriate techniques for quantifying groundwater recharge. Hydrogeol J 10: 18-39.

SCANlon BR, KeEse KE, Flint AL, Flint LE, Gaye CB, EDMUNDS WM AND SimMERS I. 2006. Global synthesis of groundwater recharge in semiarid and arid regions. Hydrol Process 20: 3335-3370.

SIMMERS I. 1989. Natural groundwater recharge estimation in semiarid zones: some state-of-art observations. Proceedings of the Sahel Forum, the State-of-Art of Hydrology and Hydrogeology in the Arid and Semi-Arid Areas of Africa, Ouagadougou, Burkina Faso, February, p. 374-386.
SingH KP AND Stall JB. 1971. Derivation of Base Flow Recession Curves and Parameters. Water Resour Res 7(2): 292-303.

SMERdon BD, ALLEN DM AND NEILSEN D. 2010. Evaluating the use of a gridded climate surface for modelling groundwater recharge in a semi-arid region (Okanagan Basin, Canada). Hydrol Process 24: 3087-3100.

SRACEK O AND HiRATA R. 2002. Geochemical and stable isotopic evolution of the Guarani Aquifer System in the state of São Paulo, Brazil. Hydrogeol J 10(6): 643-655.

TAN SBK, ShUY EB AND CHUA LHC. 2007. Effects of meteorological and hydrogeological factors on gross recharge percentage at unconfined sandy aquifers with an equatorial climate. Hydrol Process 21: 2493-2503.

TURNIPSEED DP AND SAUER VB. 2010. Discharge measurements at gaging stations: U.S. Geological Survey, Techniques and Methods book 3, chap. A8, 87 p.

WENDLAND E, BARRETO CEAG AND GOMES LH. 2007. Water balance in the Guarani Aquifer outcrop zone based on hydrogeologic monitoring. J Hydrol 342: 261-269. 
